\title{
DIE GOUE VERSE VAN PUTHAGORAS
}

\section{J.C. Thom, Departement Grieks, Universiteit van Stellenbosch}

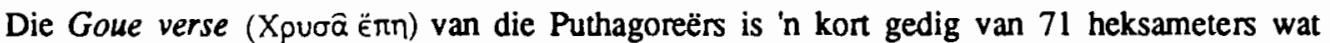
morele en godsdienstige voorskrifte bevat. Alhoewel dit vandag relatief onbekend is, selfs onder klassici, was dit baie gewild en hoogaangeskrewe in die Antieke. In hierdie artikel sal gepoog word om sommige van die redes hiervoor aan te toon.!

\section{Resepsie- en navorsingsgeskiedenis}

Die gewildheid van die Goue verse in die Antieke kan afgelei word uit die feit dat dikwels aangehaal is, o.a. deur skrywers soos Chrusippos (281/77-208/04 v.C.), Seneca (4-65 n.C.), Plutarchos (ca. $45-120$ n.C.), Epiktetos (ca. 55-135 n.C.), Galenos (129-199 n.C.), Clemens van Aleksandriě (150 - ca. 215), Origenes (185-253 n.C.), Porphurios (234-301/4 n.C.), Jamblichos (ca. 240-325 n.C.), Gregorios van Nazianzos (329/30-390/91 n.C.), Hieronimus (345-419), Calcidius (fl. 400) en Proklos (412-485). ${ }^{2}$ Daarbenewens gee Jamblichos 'n interpretasie van die tweede helfte van die gedig in hoofstuk 3 van sy Protreptikos, terwyl Hierokles van Aleksàndrië (5de eeu n.C.) 'n uitgebreide kommentaar (122 bladsye in die Teubner-uitgawe) daaraan wy. 'n Verdere kommentaar wat aan Proklos toegeskryf word, is slegs behoue in ' $n$ Arabiese vertaling (teks en vertaling deur Linley in at-Tayyib 1984). Daar bestaan 'n moontlikheid dat die outeur van hierdie kommentaar nie die bekende Proklos, hoof van die Akademie in Athene was nie, maar die sg. Proklos Prokleios wat heelwaarskynlik in die tweede helfte van die 4de eeu n.C. geleef het (Westerink 1987; O'Meara 1989:231-232).

Aan die einde van sy kommentaar gee Hierokles 'n goeie weerspieëling van die gesindheid van antieke lesers jeens die Goue verse:

\begin{abstract}
Hierdie verse is ... niks anders nie as die mees volkome uitdrukking van filosofie, 'n samevatting van die belangrikste leerstellinge daarvan, 'n elementêre onderwysing wat neergepen is deur diegene wat al gevorder het op die heilige weg vir diegene wat ná hulle kom. ' $n$ Mens sou dit inderdaad ook' $n$ allermooiste teken van menslike adel kon noem, 'n nalatenskap van nie slegs een Puthagoreër nie, maar van die hele heilige vergadering, en soos hulle self sou sê, 'n gesamentlike uitspraak van die skool as geheel. (Hierocl. in CA 27.11)
\end{abstract}

Die Goue verse is oorgelewer in 'n menigte manuskripte, sommige met uitvoerige glosse en parafrases. Sedert die editio princeps (Venisië, 1494) is dit herhaaldelik uitgegee, gewoonlik met kommentaar, en tot diep in die vorige eeu het dit gereeld 'n plek gevind in skooluitgawes van Griekse digkuns.

1 Hierdie artikel is ' $n$ vertaling en effense verwerking van ' $n$ referaat wat gelewer is by die jaarvergadering van die Society of Biblical Literature in November 1989 te Anaheim, Californie. Vir 'n omvattende studie van hierdie gedig sien Thom 1990.

2 Chrusippos ap. Gellius 7.2.12 = SVF 2.100; Arr. Epict. Diss. 3.10.2-3, 4.6.32-35; Plut. Consol. ad Apoll. 29.116ef; De superst. 7.168b; De curios. 1.515f; [Plut]] Vit. Hom. 153; Galen. De propriorum

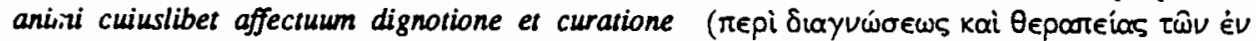

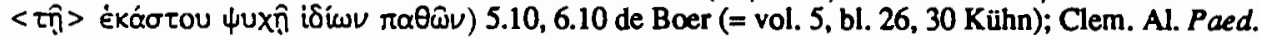
1.10.94.1; Origen. frg. in Ps. 4:5, bl. 74.8-9 Cadiou; Porph. VP 40; Iambl. VP 144; Greg. Naz. Or. 4.102.6-7 Bernardi; Hieron. c. Rufin. 3.39; Calcid. in Tim. 136; Procl. in Tim. 1, bl. 203.26; 3, bl. 53.5 Diehl. 
'n Kritiese reaksie het egter ingetree in die tweede helfte van die 19de eeu. Vantevore is die gedig geassosieer met Puthagoras of een van sy onmiddellike studente. Geleerdes soos Nauck (1873, 1884), Cobet (1878:460-469) en Zeller (1923:1.378) het nou 'n veel latere datering bepleit. Hulle wys op die gebrek aan samehang, die weerspreking van vroeg-Puthagorese leerstellinge, die relatief lomp Grieks en metrum, en die gebruik van woorde wat nie elders voorkom voor die laat-Hellenistiese of Keisertyd nie. Hierdie kritiese bydraes vorm die vertrekpunt van modeme studies van die Goue verse, veral dié deur Armand Delatte (1915:3-79) en P.C. van der Horst (1932).

\section{Datering van die Goue verse}

Die datering van die Goue verse is nog steeds 'n onopgeloste probleem: die datums wat deur modeme geleerdes voorgestel word, wissel met soveel as ag eeue, van die tyd van Puthagoras self aan die einde van die 6de eeu v.C. (Farina 1962: 15-17) tot die tyd van Jamblichos in die 3de en 4de eeu n.C. (Nauck 1884). Die beskikbare getuienis is die volgende:

Die interne getuienis lewer nie juis spesifieke aanduidings vir die datering op nie. Die titel "Goue verse van Puthagoras" is nie baie oud nie en word slegs in sekere manuskripte aangetref. Die titel in die oudste manuskrip (V) is slegs "Goue verse". Die vroegste eksplisiete verwysing na hierdie gedig (Alkiphron 3.19.7 Schepers) is ook slegs na die "Goue verse". Niks in die gedig dui op Puthagoras as outeur nie; inteendeel, aangesien die eed in vv. 47-48 heelwaarskynlik by Puthagoras gesweer word, kan hy beswaarlik die outeur wees!

Nauck (1884) en ander het verder veral gewys op die ongewone gebruik of laat attestasie van

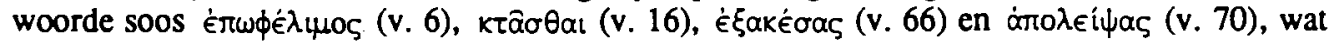
vir hulle ' $n$ aanduiding is van ' $n$ redelike laat komposisie. ${ }^{3}$ Aangesien die grootste gedeelte van die corpus van Hellenistiese tekste egter verlore is, sou dit onverantwoordelik wees om tot heel spesifieke gevolgtrekkings te geraak op grond van die feit dat 'n bepaalde vorm nie elders in tekste van hierdie periode voorkom nie. Ons kan hoogstens aflei dat die Goue verse heelwaarskynlik nie voor die Hellenistiese tyd geskryf is nie. Aspekte soos styl en metrum waama Nauck ook verwys, bied nog minder definitiewe aanduidings.

Kyk ons na die eksterne getuienis, is die probleem dat hoewel Chrusippos reeds v. 54 aanhaal as iets wat "deur die Puthagoreërs gesê word" (SVF 2.1000), daar nie na die Goue verse by name verwys word voor die tyd van Alkiphron (3.19.7 Schepers) en Jamblichos (Protr. 3, bl. 10) nie, d.w.s., nie voor die 3de eeu n.C. nie. Die vraag is dus of Chrusippos en ander skrywers soos Plutarchos, Epiktetos en Clemens wat wel voor hierdie tyd verse uit die gedig aanhaal, die gedig in sy huidige vorm geken het, en of hulle nie miskien na ander, vroeër Puthagorese tekste en spreuke verwys nie. Hierdie materiaal kon dan ook deur die skrywer van die Goue verse gebruik gewees het om die huidige gedig saam te stel. Lg. is die standpunt van die meeste resente geleerdes, wat die gedig dus in die 2de eeu n.C. of selfs later dateer (Nauck 1884, Delatte 1915, Van der Horst 1932). M.i. is die interne getuienis egter nie sterk genoeg om so 'n laat datering af te dwing nie. Die gedig kon dus reeds in Chrusippos se tyd in die 3de eeu v.C. bestaan het - of op die laaste in die 1ste eeu v.C. ontstaan het, toe vele ander Pseudo-Puthagorese tekste ook hulle verskyning gemaak het (só Zeller 1923:1.378) - maar eers in 'n latere stadium sy huidige naam gekry het.

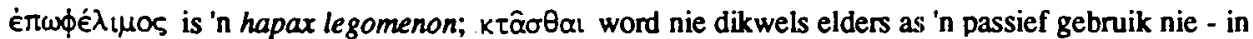
elk geval nie voor Dio Cassius (2de/3de eeu n.C.) 38.38.3 Melber nie; $\dot{\xi}$ oxéơas kom gewoonlik nie in die aktief voor nie - die vroegste ander voorbeeld is Marcellus Sidetis (begin 2de eeu n.C.) De

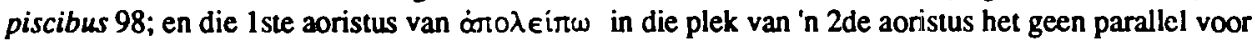
Pseudo-Phokulides (1ste eeu v.C. of 1ste eeu n.C.) 77 en Themistius (4de eeu n.C.) Orationes $25.310 \mathrm{~d}$ nie, hoewel daar 'n onsekere voorbeeld van die 1ste aoristus van $\lambda \in i \pi \omega$ in Antiphanes (4de eeu v.C.) frg. 32 Kock voorkom. 


\section{Genre en funksie}

Die verband wat die Goue verse het met die Griekse gnomiese of wysheidsliteratuur, is ooglopend. Die eerste 49 verse in die besonder vertoon 'n groot ooreenkoms met ander gnomiesparenetiese tekste soos die Spreuke van Axiopistos, die Spreuke van Chares, die Spreuke van Demokritos, [Isokrates] Aan Demonikos (veral parr. 13-43), die Kuriai doxai van Epikuros, die Spreuke van Pseudo-Phokulides, die Spreuke van Menandros, die Spreuke van Sextus, ens. (Sien die waardevolle oorsig van hierdie materiaal by Küchler 1979:240-259 en Kloppenborg 1987:295-306, 337-340.) By nadere ondersoek blyk dit dat hierdie materiaal 'n groot verskeidenheid moontlikhede verteenwoordig in terme van vorm, inhoud en funksie. Aan die een kant van die spektrum is daar gnomologia soos die Spreuke van Menandros: dit is 'n "blote versameling" van spreuke; daar is geen ordenende beginsel behalwe 'n alfabetiese rangskikking nie; die funksie van die versameling is klaarblyklik net om die spreuke in 'n hanteerbare formaat te bewaar vir kontemporêre en toekomstige lesers. In die middel van die spektrum vind ons versamelings wat losweg georden is rondom topoi soos rykdom en armoede, vriende en vyande, goeie en slegte vroue, losbandigheid en kuisheid, ens. Die meeste van die tekste wat hierbo genoem is val in hierdie groep. Aan die anderkant van die spektrum kom daar weer werke soos die Goue verse voor: hulle vertoon dieselfde losse tematiese rangskikking as die vorige groep, maar daarby het hulle ook ' $n$ oorkoepelende betekenis en funksie. In die Goue verse (soos ons binnekort sal sien) vind daar 'n liniêre en doelgerigte ontwikkeling plaas: 'n spesifieke lewenswyse word in die eerste gedeelte van die gedig voorgehou, gevolg deur ' $n$ aanduiding van die (eskatologiese) voordele van so 'n lewe, in die tweede gedeelte. Die funksie van die Goue verse is klaarblyklik om die leser op 'n samevattende wyse in te lei in 'n heel spesifieke lewenswyse. Dit is ook die geval met die Kuriai doxai van Epikuros, en miskien ook waar van Pseudo-Phokulides.

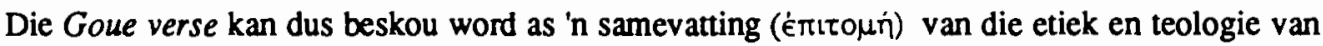
'n Puthagorese groep (vgl. Hierocl. in CA 27.11 wat hierbo aangehaal is). As sodanig het dit gefunksioneer as beide ' $n$ inleiding vir nuwe lede en ' $n$ samevatting vir ouer lede. Uit die testimonia is dit verder duidelik dat dit gebruik is vir psugagogie, d.w.s., die begeleiding van studente tot geestelike volwassenheid (vir psuchagogie, sien Rabbow 1954; I Hadot 1969, 1986; P Hadot 1987); die gedig is nie net gememoriseer nie, maar ook minstens tweemaal per dag opgese; spesifieke verse is in kritiese omstandighede gebruik om die student in sy morele oortuiging te sterk en hom te herinner aan die beginsels wat in so 'n situasie toegepas moet word (vgl. Alkiphron 3.19.7; Galenus De affect. dignot. 6.10; Hierocl. in CA 27.12; Arr. Epict. Diss. 3.10.1-4; Porph. VP 40; Diog. Laert. 8.22). Ander Griekse tekste wat op soortgelyke wyse gebruik is, is die Kuriai doxai van Epikuros en die Encheiridion van Epiktetos.

\section{Teks en vertaling}

Die teks wat volg is dié van Diehl en Young (1971:86-94); die apparaat dui slegs aan waar ek afwyk van hulle uitgawe. Ander resente teksuitgawes deur Nauck (1884), Van der Horst (1932) en Farina (1962) verskil nie noemenswaardig van Diehl en Young s'n nie. 


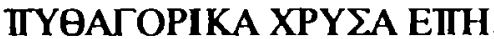

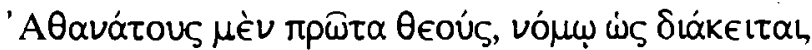

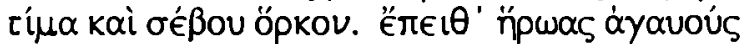

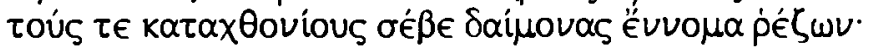

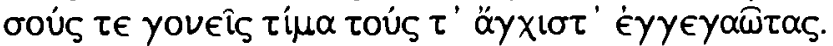

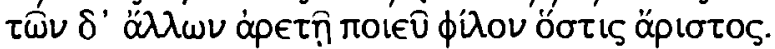

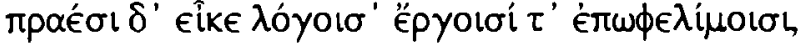

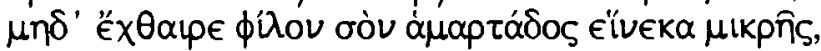

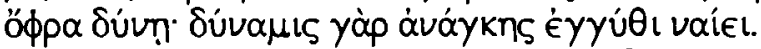

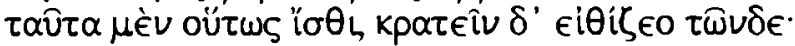

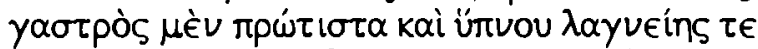

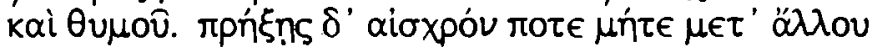

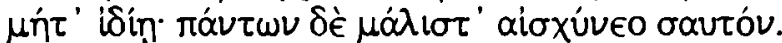

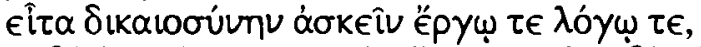

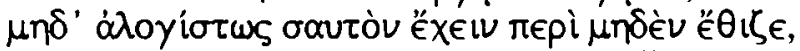

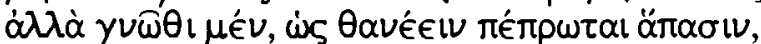

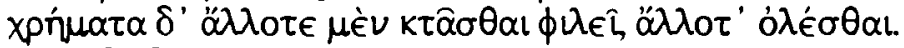

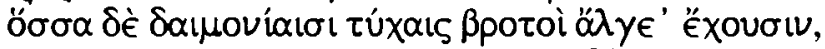

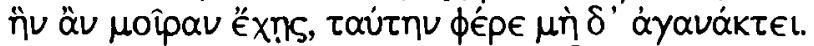

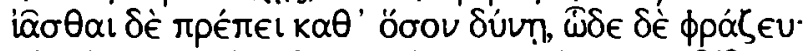

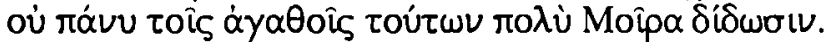

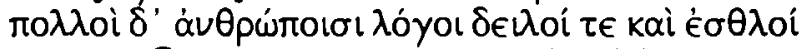

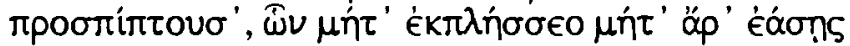

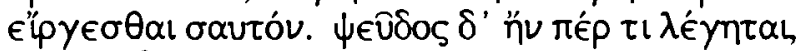

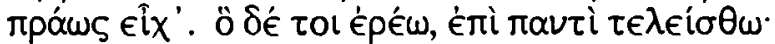

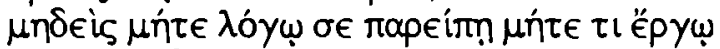

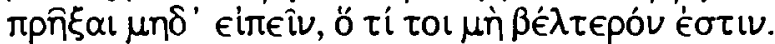

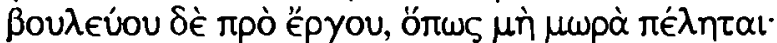

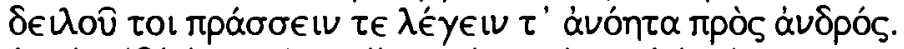

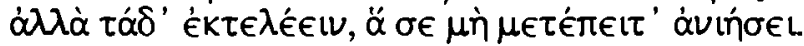

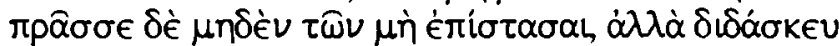

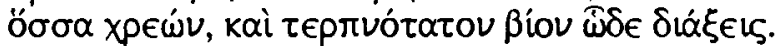

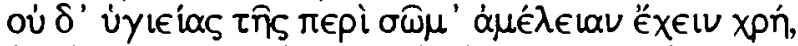

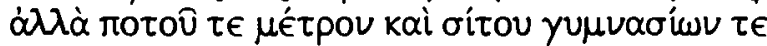

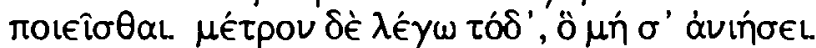

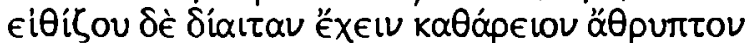

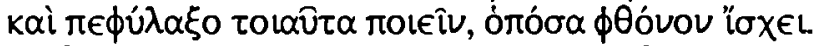

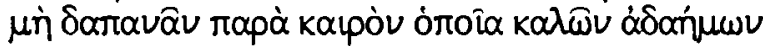

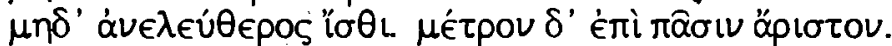

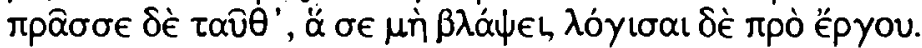

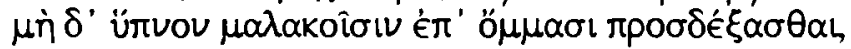

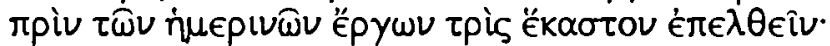

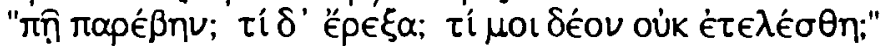

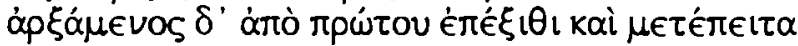

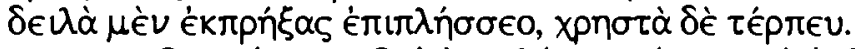

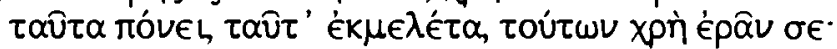

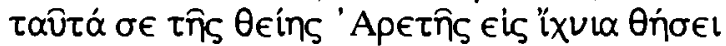

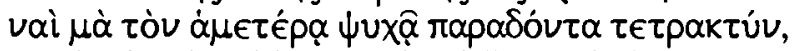

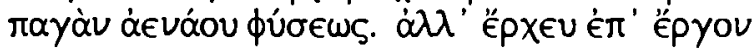

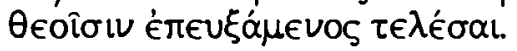




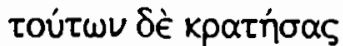

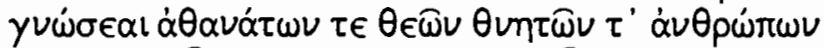

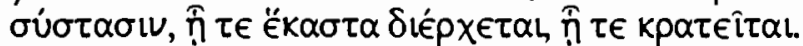

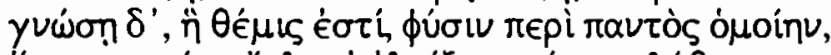

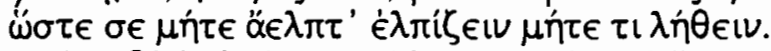

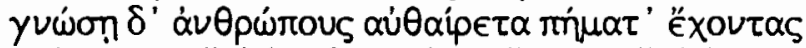

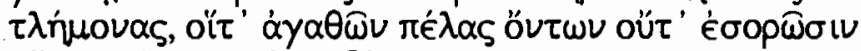

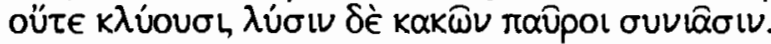

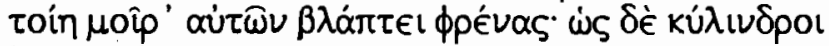

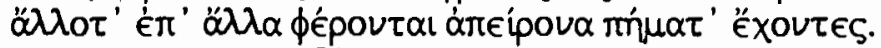

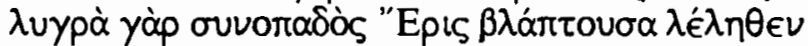

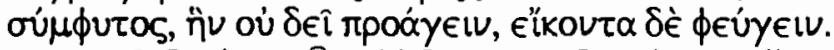

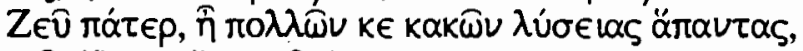

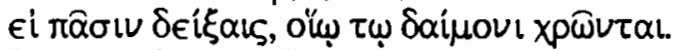

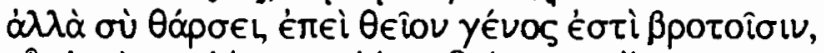

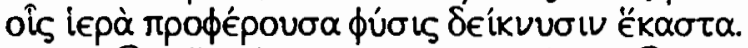

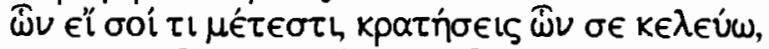

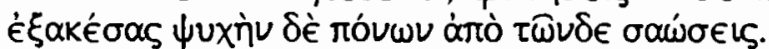

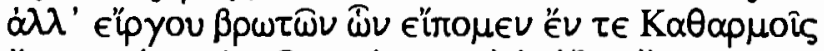

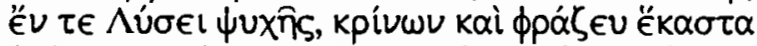

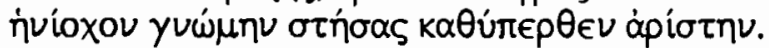

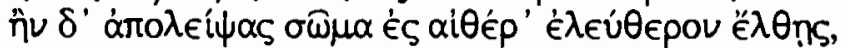

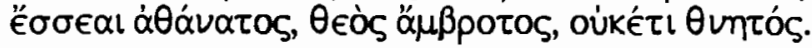

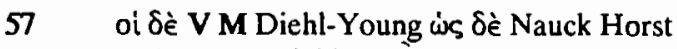

$61 \tau \in$ MSS $y \in$ Diehl-Young $k \in$ Nauck Horst

\section{PUTHAGORESE GOUE VERSE}

Eer eers die onsterflike gode, soos die wet bepaal, en eerbiedig.jou eed. Betoon daama eerbied aan die luisterryke helde en die onderaardse geeste deur die voorgeskrewe rites.

Eer dan jou ouers en hul naaste bloedverwante.

Wat die ander betref, maak hom tot vriend wat uitstaan in deug.

Gee toe aan sagte woorde en behulpsame dade,

en moenie jou vriend haat om 'n klein oortreding nie,

so lank as wat jy kan; want moontlikheid woon digby noodsaaklikheid.

Ken bogenoemde dus, en wees gewoond om oor die volgende te heers:

eerstens oor jou maag, oor slaap, oor wellus.

en oor woede. Doen nooit iets skandeliks nie, nòg saam met 'n ander,

nòg op jou eie. Behou bowenal respek vir jouself.

Beoefen verder geregtigheid in daad en woord,

en wees gewocnd om in niks onnadenkend te wees nie,

maar weet dat dit vir almal bestem is om te sterwe,

en dat eiendom geneig is om een oomblik verwerf te word, dan weer verlore te gaan.

Watter pyne sterflinge ly weens goddelike lotgevalle, watter lot jy ookal het, dra dit sonder om kwaad te word.

Jy behoort dit te genees so ver as wat jy kan, en dink so daaroor.

die Lotsgodin gee nie baie hiervan vir die goeies nie. 
Baie woorde kom mense teë, goed sowel as sleg moenie jou daaroor verwonder of jou laat ontstel nie. As iets vals egter gesê word, gee saggies pad. Maar wat ek vir jou sal sê moet in alle geval gedoen word:

laat niemand jou met woord of daad oothaal

om te doen of te sê wat nie die beste vir jou is nie.

Besin voor die daad, sodat daar nie dwaashede gebeur nie;

dis tipies van 'n slegte mens om onbesonne dinge te doen of te sê.

Bring dít egter tot uitvoer wat jou nie later sal pla nie.

Doen nie eers een ding wat jy nie verstaan nie, maar leer

wat nodig is, en jy sal so ' $n$ baie aangename lewe deurbring.

Jy moenie onverskillig staan teenoor jou liggaamlike gesondheid nie,

maar beoefen matigheid in drank en kos en oefening. Met matigheid bedoel ek dit wat

jou nie sal pla nie.

Wees gewoond om 'n suiwer, onopgesmukte lewe te voer

en pasop om die soort dinge te doen wat afguns meebring.

Moenie ontydig geld uitgee soos een onkundig van wat goed is nie,

maar moenie vrekkerig wees nie. Matigheid is in alles die beste.

Doen dit wat jou nie sal skaad nie, en besin voor die daad.

Moenie die slaap op jou sagte oë verwelkom

voordat jy nie elkeen van die dag se handelinge driemaal oorgegaan het nie:

"Waar het ek oortree? Wat het ek verrig? Watter plig het ek nie nagekom nie?"

Begin vanaf die eerste en gaan dit oor, en daama,

as jy slegte dinge gedoen het, berispe jouself, maar as jy goeie dinge gedoen het, wees bly.

Werk aan hierdie dinge, oefen hierdie dinge, hierdie dinge moet jy begeer,

hierdie dinge sal jou in die voetspore van die goddelike Deug plaas,

ja, by hom wat aan ons siel die tetraktus oorgelewer het,

bron van die ewige natuur. Maar gaan oor tot die daad

en bid die gode om voltooiing.

As jy hierdie dinge bemeester,

sal jy die band tussen onsterflike gode en sterflike mense leer ken,

hoe dit elke ding deurdring, hoe elke ding daardeur beheer word.

Jy sal die natuur leer ken - wat geoorloof is - as dieselfde in alles,

sodat jy nie die onverwagbare verwag nie, en niks jou aandag ontglip nie.

Jy sal agterkom dat mense selfgekose smarte ly,

die ellendiges, wat die goeie wat naby is ndg sien,

nog hoor, en min verstaan die verlossing uit hul ellende.

So ' $n$ lot skaad hulle verstand: soos tuimelende rotse

word hulle hierheen en daarheen gevoer terwyl hul eindelose smarte ly.

Want 'n verderflike, ingebore metgesel, Tweedrag, skaad hulle

onbewustelik - wat 'n mens nie moet bevorder nie, maar van moet wyk en vlug.

Vader Zeus, u sou beslis almal van baie kwaad red,

as u vir almal sou wys watter soort daimon hulle het.

Maar hou jy moed, want daar is 'n goddelike geslag onder sterflinge

vir wie die natuur alle heilige dinge tevoorskyn bring en wys.

As jy ook deel daaraan het, sal jy bemeester wat ek jou beveel

en jy sal jou siel genees en van hierdie sorge red.

Weerhou jou egter van voedsel waama ons verwys het in die Reinigings

en die Verlossing van die siel, terwyl jy alles beoordeel en oorweeg

deur die beste oordeelsvermoß̈ as drywer in bevel aan te stel.

As jy dan die liggaam verlaat en na die vrye eter gaan,

sal jy onsterflik wees, 'n onverganklike god, nie langer sterflik nie. 


\section{Struktuur}

Gnomiese tekste is berug vir hul gebrek aan struktuur en die meeste geleerdes kritiseer dan ook die Goue verse vir sy onsamehangendheid. Na my mening is die gedig egter nie net ' $n$ versameling van losstaande spreuke nie, maar toon dit blyke van 'n redelike mate van organisasic en integrasie. Dit sou egter te veel tyd in beslag neem om hierdie standpunt in detail te verdedig; ek volstaan dus met 'n kort oorsig van die gedig se komposisie (vir 'n meer omvattende bespreking, sien Thom 1990).

1-49a I. Voorskrifte wat bemeester moet word

$1-8$

$1-4$

$5-8$

9-49a

9-20

9

10-12

13

14-16

17-20

$21-26$

27-44

27-39

27-31

32-38

39

40-44

$45-49 a$

49b-71

$49 \mathrm{~b}-64$

$49 \mathrm{~b}$

50-51

$52-53$

54-60

$61-62$

63-64

65-71

65

66

67-69

70-71

A. Verhoudings met ander

1. Vertikale verhoudings

2. Horisontale verhoudings

B. Beoefening van deug

1. Die kardinale deugde

a) Opsommende bevele

b) Voorskrifte aangaande selfbeheersing ( $\sigma \omega \phi \rho \circ \sigma u ́ v \eta$ )

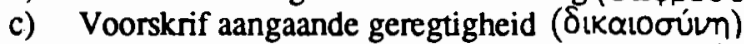

d) Voorskrifte aangaande morele insig (фpóvnoıs)

e) Voorskrifte aangaande morele moed ( $\dot{\alpha} \nu \delta \rho \in i \alpha)$

2. Morele insig en lering

3. Besinning en nabetragting

a) Besinning oor dade en hul gevolge

(1) фpóunots

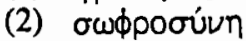

(3) фpóvnols (samevatuing)

b) Nabetragting en selfondersoek

4. Samevattende bevele om voorskrifte te beoefen

II. Uiteindelike doelstellings en voordele

A. Insig in metafisiese probleme

1. Voorwaarde: bemeester voorskrifte

2. Belofte van insig in verhouding tussen gode en mense

3. Belofte van insig in die natuur

4. Belofte van insig in die die oorsake van lyding

5. Gebed om verlossing uit ellende

6. Trooswoord

B. Slot

1. Belofte dat voorskrifte bemeester sal word

2. Belofte van verlossing uit swaarkry

3. Voorskrif aangaande onthouding van sekere voedsel

4. Finale belofte van onsterflikheid

Die gedig kan in twee basiese dele verdeel word. Deel I (vv. 1-49) bevat hoofsaaklik voorskrifte en word gekenmerk deur die oorheersende gebruik van imperatiewe. Deel II (vv. 50-71) bevat beloftes en dui die uiteindelike doelstellings aan; gevolglik tref ons hier meer indikatiewe as imperatiewe aan. Die hele gedig vertoon dus ' $n$ voorwaardelike struktuur op die makrovlak: "As jy doen wat ek jou in die eerste deel beveel, dan sal jy deel hê aan die voordele wat in die tweede deel beloof word." 
Deel I begin met ' $n$ gedeelte wat te make het met ons verhoudings met ander. eers met wescns en persone wat ons meerderes is (vv. 1-4), dan met persone op ons eie vlak (vv. 5-8). Eg. groep word in 'n dalende hiërargie opgenoem (gode, helde, daimones, ouers en ander familie); die gepaste houding is respekvolie vroomheid. Die bepalende verhouding binne die tweede groep is vriendskap.

Die volgende gedeelte bevat voorskrifte aangaande die deugde wat bemeester en beoefen moet word ten einde vordering te maak wat betref geestelike volwassenheid. Dit is verrewcg die langste gedeelte (vv. 10-49) en maak die etiese kem van die gedig uit. Dit kan self weer in vier onderafdelings verdeel word. Die eerste het te make met die kardinale deugde: selfbeheersing

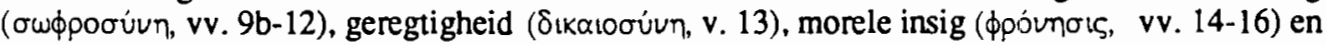

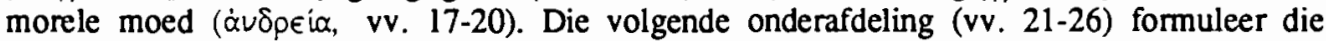
korrekte maatstaf om t.o.v. leringe aan te lê: vermy wat nie die beste vir jou is nie. Hierdie formulering is 'n toepassing van morele insig. Die derde onderafdeling fokus op twee van die deugde in die besonder, $n \mathbf{l}$. morele insig en selfbeheersing. Die eerste gedeelte hiervan (vv. $27-$ 39) het te make met besinning v60r handeling om moontlike negatiewe gevolge te vermy, terwyl die tweede gedeelte ( $v v .40-44$ ) weer betrekking het op nabetragting en selfevaluering ná handeling. Die laaste onderafdeling (vv.45-49a) sluit Deel I af deur die student te vermaan om die gegewe voorskrifte te beoefen ten einde die verlangde toestand van deug te bereik. Ter bevestiging haal die skrywer die bekende eed by Puthagoras, die ontdekker van die tetraktus, aan. Die tetraktus was 'n komplekse simbool vir die Puthagorese insig in die geheimenisse van die natuur, en as sodanig funksioneer die verwysing daama as 'n draaipunt in die oorgang na Deel II waarin na sommige van hierdie geheime verwys word. ${ }^{4}$

Deel II dui die uiteindelike doelstellings en voordele aan van die lewenswyse wat in die gedig gepropageer word. Hierdie deel is aansienlik meer kompleks as die eerste, hoofsaaklik omdat daar slegs verwys word na toekomstige insigte en meer gevorderde leerstellinge sonder om hulle te verduidelik. Die eerste gedeelte (vv. 50-64) noem die insigte op wat die student sal verkry: insig in die verband tussen gode en mense (vv. 50-51), in die natuur (vv. 52-53) en in die oorsaak van lyding (vv. 54-60). Dit sluit af met 'n gebed aan Zeus om die persoonlike daimon ${ }^{5}$ te openbaar (vv. 61-62) en met 'n vertroosting wat gebaseer word op die goddelike oorsprong van die mens en op die moontlikheid om deel te hê aan die misteriekultus van die natuur (vv. 63-64). Die slotgedeelte (vv. 65-71) bevat finale beloftes en bevele. Hierdie bevele hou weer verband met selfbeheersing en morele insig. Daar is ook 'n verwysing na twee ander geskrifte van hierdie groep, t.w. die Reinigings en die Verlossing van die siel. Die finale belofte maak eksplisiet wat tot dusver slegs gesuggereer is, nl, dat die uiteindelike doel 'n onsterflike en goddelike bestaan in die hiemamaals is.

\section{Godsdienstige idees}

Die basiese tema van die Goue verse kan in een woord saamgevat word, nl. insig. Dwarsdeur die gedig word nadruk gelê op insig. In die eerste deel van die gedig gaan dit oor morele insig, insig in die morele implikasie van 'n mens se dade. Die doel van hierdie insig is die vermoë om enigiets te vermy wat die siel kan verhinder onderweg na morele volkomenheid. Alhoewel hierdie insig 'n suiwer praktiese toepassing het, behels dit nie spesifieke, inhoudelike kennis nie; dit behels veel meer 'n lewenswyse, 'n ingesteldheid jeens handeling en praktiese alledaagse aangeleenthede.

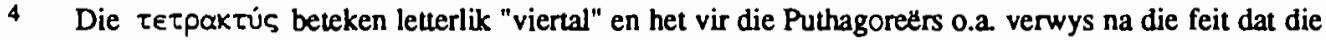
som van die eerste vier integers die getal 10 vorm; dit "bevat" dus in 'n sekere sin alle ander getalle en dus (vanuit Puthagorese perspektief) alle numeriese verhoudinge waarvit die natuur saamgestel is (Delatte 1915:253-264; Burkert 1972:72-73, 186-188; Van der Waerden 1979:105-110).

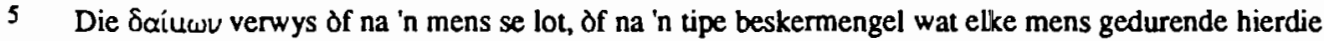
lewe begelei. 
Meer spesifiek het dit enersyds te make met 'n bewuswees van die eksistensiële parameters van die menslike kondisie en die beperkings wat daardeur op die mens se aktiwiteit geplaas word. Die mens is in die eerste plek betrokke in allerhande stelle verthoudings, jeens die gode, familie en ander mense, wat almal 'n bepaalde respons vereis ( $v v .1-8$ ). Die mens is ook onderworpe aan fisiese drange en irrasionele hartstogte wat beheer moet word indien hy ' $n$ dierlike bestaanswyse wil oorskry (vv. 9-12). In die derde plek het die mens baie min beheer oor die omstandighede wat sy bestaan bepaal; die dood veral bied 'n finale grens waaraan die mens nie kan ontkom nie. Aangesien die wisselvallighede van die lewe nie beheer kan word nie, moet hulle verduur word (vv. 14-20). Vierdens is die mens blootgestel aan die wil en menings van sy medemens; hy moet dus ' $n$ modus vivendi vind om homself te kan handhaaf teenoor die mag van oorreding (vv. 2126). Die mens het ook 'n liggaam waarvoor hy moet sorg; hy het eiendom om te bestuur, kortom, hy moet vir homself ' $n$ lewenstyl uitwerk (vv. 32-38).

Andersyds behels morele insig 'n stel maatstawwe om aan te lê in alles wat 'n mens doen, die basiese beginsel synde of ' $n$ bepaalde handeling bydra tot die uiteindelike morele goed van die agent al dan nie (vgl. vv. 25-26, 27, 29, 31, 34, 39). Dit bring mee dat handeling bewus, besonne en rasioneel moet word. Om hierdie doel te bereik moet die morele agent homself daaraan gewen om voortdurend te besin voor enige handeling om so ver as moontlik 'n voordelige afloop te verseker ( $v v .27,39$ ); hy moet ook daaglikse retrospeksie beoefen om sy vordering te monitor en om 'n herhaling van foute te vermy (vv, 40-44). Beheer, oefening. gewenning, besinning en nadenke is dus sleutelwoorde in hierdie lewenswyse (vgl. vv. 9, 13, 14, 27, 35, 39, 40-45, 49, 65, 67-68).

In die tweede deel van die gedig word 'n ander vorm van insig belowe, nl. insig in verskillende metafisiese aangeleenthede. Hierdie insig is afhanklik van vordering in morele insig en dit het ook morele implikasies. Die bepaalde metafisiese vraagstukke word ook vry algemeen gevind in ander Grieks-Romeinse filosofiese en filosofies-godsdienstige tekste, veral in werke wat ten doel het om die leser in te lei in 'n bepaalde filosofiese of godsdienstige tradisie (Dórrie en Dörrie 1966; Norden 1923:99-109). Die eerste probleem het te make met die band wat gode en sterflinge saambind (vv. 50-51). Die tweede probleem het betrekking op die struktuur van die natuur (vv, 52-53). Insig sal verwerf word in die verweefdheid en homogeniteit daarvan. Op grond hiervan sal die student in staat wees om valse verwagtings te vermy; dit sal ook sy bewussyn van gebeurtenisse rondom hom verhoog. Die derde en belangrikste vraagstuk vir die skrywer het te make met die oorsaak van lyding ( $v v$. 54-60). In ooreenstemming met 'n lang tradisie waarin Plato hom ook o.a. bevind (vgl. Resp. 617e), verklaar die skrywer dat die mens self vir sy lyding verantwoordelik is; lyding is inderdaad "selfgekose". Anders as by Plato egter die geval is, word die oorsprong van lyding nie teruggevoer na 'n protologiese keuse voor die inkarnasie van die siel nie, maar word dit eenvoudig toegeskryf aan onkunde jeens die goeie en jeens die moontlikheid van verlossing. Onkunde bring mee dat ' $n$ mens onderworpe is aan ' $n$ innerlike tweespalt. Omdat mense nie beskik oor duidelike maatstawwe op grond waarvan ' $n$ rasionele keuse tussen verskillende moontlikhede gemaak kan word nie, word hulle heen en weer geslinger, en in die proses ly hulle skade soos rotse wat buite beheer teen 'n berg af tuimel

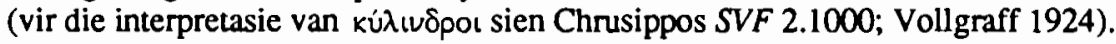

Aangesien die oorsaak van lyding onkunde of die gebrek aan insig is, is die oplossing, soos te wagte is, die insig wat in die gedig gepropageer word. In die eerste deel van die gedig word die student beveel om lyding te verduur sonder om ergerlik te word omdat lyding beperk is wat goeie mense betref (vv. 17-20). Die beoefening van die deugde wat in die eerste deel aanbeveel word, het ook meestal 'n voorkomende doel: om dit te vermy wat 'n mens sal ontstel en benadeel (vgl. vv. 27, 29, 34, 36, 39). Hier, in die tweede deel, word die insig in 'n mens se metafisiese status en jou plek in die natuur aangebied as 'n teenmiddel vir lyding (vgl. vv. 61-64), aangesien sodanige insig ' $n$ mens in staat sal stel om handelinge met negatiewe gevolge te vermy. Aan die einde van die gedig herhaal die skrywer dat deelname aan die geheime insig wat deur sy groep verskaf word, en die bemeestering van die voorskrifte wat in die gedig gegee word, die siel sal genees en dit van lyding sal verlos (vv. 65-66). Hierdie bevrydingsproses kulmineer in die dood, wanneer die siel weer vry is om terug te keer na sy inheemse eter as ' $n$ goddelik een onsterflike wese (vv. 70-71). 
Om op te som: die gedig bied 'n program vir die lewe; sy doel is om die leser te lei sodat lg. die slaggate van hierdie lewe sal vermy en sy regmatige metafisiese status as familielid van die gode sal herwin. Die gedig se doel is dus uiteindelik godsdienstig van aard. Aangesien hierdie bedoeling herken en gewaardeer is deur opgevoede lesers in die Antieke, is die Goue verse 'n waardevolle getuienis van ' $n$ vorm van filosofiese godsdiens. Die gedig vorm dus deel van 'n beweging wat kenmerkend was van die laat Antieke, ' $n$ beweging wat bestempel kan word as ' $n$ heiliging van die filosofie, waarin die filosofie gepoog het om te voldoen. aan die godsdienstige behoeftes van die opgevoede mens (vgl. Nock 1972:1.508; Colpe 1988:211-215).

\section{Bibliografie}

Burkert, W. 1972. Lore and science in ancient Pythagoreanism. Trans. E.L. Minar, Jr. Cambridge, Massachusetts: Harvard University.

Cobet, C.G. 1878. Collectanea critica: Observationes criticae inscriptores Graecos. Leiden: Brill.

Colpe, C. 1988. Heilige Schrifte. Reallexikon für Antike und Christentum 14:184-223.

Delatte, A. 1915. Études sur la littérature pythagoricienne. Paris: Champion. (Bibliothèque de l'École des Hautes Études 217.)

Diehl, E. \& Young, D. (eds.) 1971. Theognis, Ps.-Pythagoras, Ps.-Phocylides, Chares, Anonymi aulodia, Fragmentum Teliambicum. 2de ed. Leipzig: Teubner. (Bibliotheca scriptorum Graecorum et Romanorum Teubneriana.)

Dörrie, H. \& Dörrie, H. 1966. Eratapokriseis. Reallexikon für Antike und Christentum 6:342370.

Farina, A. 1962. I versi aurei di Pitagora: Introduzione, testo critico, testimonianze, traduzione, commento. Napoli: Libreria Scientifica Editrice. (Collana di studi greci 35.)

Hadot, I. 1969. Seneca und die griechisch-römische Tradition der Seelenleitung. Berlin: de Gruyter. (Quellen und Studien zur Geschichte der Philosophie 13.)

Hadot, 1. 1986. The spiritual guide. Trans. M. Kirby. In Classical mediterranean spirituality: Egyptian, Greek, Roman, ed. A.H. Armstrong. New York: Crossioad, 436-459. (World Spirituality 15.$)$

Hadot, P. 1987. Exercices spirituels. In Exercices spirituels et philosophie antique. 2e éd. Paris: Études Augustiniennes, 13-58.

Horst, P.C. van der 1932. Les vers d'or pythagoriciens. Leiden: Brill.

Kloppenborg, J.S. 1987. The formation of $Q$ : Trajectories in ancient wisdom collections. Philadelphia: Fortress. (Studies in Antiquity and Christianity.)

Küchler, M. 1979. Frühjüdische Weisheitstraditionen: Zum Fortgang weisheitlichen Denkens im Bereich des frühjüdischen Jahweglaubens. Freiburg Schweiz: Universitätsverlag. (Orbis Biblicus et Orientalis 26.)

Nauck, A. 1873. Über die goldenen Sprüche des Pythagoras. Bulletin de l'Académie des Sciences de Saint-Pétersbourg 18:472-501.

Nauck, A. 1884. Epimetrum de Pythagorae aureo carmine. In Iamblichi de vita Pythagorica liber, ed. A. Nauck. St. Petersburg: Eggers \& Glasunof, 201-242. 
Nock, A.D. 1972. Essays on religion and the ancient world. Ed. Z. Stewart. 2 vols. Oxford: Clarendon.

Norden, E. 1923. Agnostos Theos: Untersuchungen zur Formengeschichte religiöser Rede. Leipzig: Teubner.

O'Meara, D.J. 1989. Pythagoras revived: Mathematics and philosophy in Late Antiquity. Oxford: Clarendon.

Rabbow, P. 1954. Seelenführung: Methodik der Exerzitien in der Antike. München: Kösel.

at-Tayyib, Ibn, 1984. Proclus' commentary on the Pythagorean Golden verses. Ed. and trans. N. Linley. Buffalo: Department of Classics, State University of New York at Buffalo. (Arethusa Monographs 10.)

Thom, J.C. 1990. The Golden Verses of Pythagoras: Its literary composition and religiohistorical significance. Ph.D. diss., University of Chicago.

Vollgraff, W. 1924. De lapide cylindro. Mnemosyne 52:207-211.

Waerden, B.L. van der 1979. Die Pythagoreer: Religiöse Bruderschaft und Schule der Wissenschaft. Zürich: Artemis. (Die Bibliothek der alten Welt, Reihe Forschung und Deutung.)

Westerink, L.G. 1987. Proclus commentateur des Vers d'or. In Proclus et son influence. Actes du colloque de Neuchâtel, Juin 1985. Ed. G Boss et G Seel. Zürich: Grand Midi, 61-78:

Zeller, E 1923. Die Philosophie der Griechen in ihrer geschichtlichen Entwicklung. 1. Bd. 7. Aufl. Hrsg. W. Nestle. Leipzig: Reisland. 